\title{
KASIH YESUS KRISTUS DI SALIB: Jawaban Tuntas atas Misteri Penderitaan Manusia
}

\author{
Alfonsus Ara*
}

\begin{abstract}
Abstrak
Penderitaan berasal dari kodrat manusia sebagai makhluk ciptaan yang terbatas dan dosa-dosa yang dilakukan manusia sendiri. Namun, penderitaan itu dikalahkan oleh kasih Yesus di salib. Dalam "kasih" Yesus, manusia akan menemukan dan memahami cakupan makna fundamental dan definitif dari penderitaan itu sendiri. Karena kasih, Dia memberikan rela tinggal bersama manusia yang menderita, memikul penderitaan manusia serta wafat di salib demi keselamatan manusia.

Gereja dipanggil untuk masuk ke dalam kehidupan Yesus yang menderita dan wafat di salib karena kasih-Nya demi keselamatan umat manusia. Hanya dengan cara demikian, Gereja mampu menjelaskan dan bisa menjadi jalan keselamatan bagi orang-orang yang belum mengenal dan mengimani Yesus Kristus sebagai Allah dan Penebus.
\end{abstract}

Kata-kata kunci: Misteri, penderitaan, kasih, ada bersama dan untuk, mengenakan penderitaan, memikul penderitaan, wafat, bangkit, menebus, membebaskan, menyelamatkan.

\section{Realitas Penderitaan Manusia}

Ketika mengalami penderitaan, manusia selalu bertanya, berusaha mencari asal-muasalnya, bahkan menggugat dan mempertanyakan keberadaan Allah sebagai Sang Pencipta. Manusia juga meragukan kedalaman cinta dan kebaikan Allah serta mempertanyakan makna dan tujuan hidupnya sendiri. Gugatan manusia kepada Allah terangkum dalam tiga pertanyaan fundamental ini: "Dari manakah asal/sumber penderitaan yang sesungguhnya? Di manakah Allah? Apakah Allah diam saja? ${ }^{1}$

1 Paus Yohanes Paulus II, Surat Apostolik Salvifici Doloris (Penderitaan yang Menyelamatkan) (Seri Dokumen Gerejawi no. 29), diterjemahkan oleh J. Hadiwikarta (Jakarta: Departemen Dokumentasi dan Penerangan KWI, 1993), no. 9. Untuk penulisan catatan kaki selanjutnya, dokumen ini akan disingkat Salvifici Doloris dan diikuti nomor dokumen. 
Berhadapan dengan pertanyaan-pertanyaan ini muncul aneka tanggapan dan reaksi yang berbeda. Tradisi iman klasik menjelaskan bahwa penderitaan manusia berakar pada kejahatan (malum), baik yang berwujud kekurangan, keterbatasan maupun penyimpangan dari sesuatu yang baik. Menurut tradisi ini, manusia menderita karena tidak adanya kebaikan di dalam dirinya. Namun, pendapat lain yang menggali dan menyimpulkan isi ajaran Perjanjian Lama memaparkan beberapa jawaban mendasar, di antaranya:

Pertama, penderitaan merupakan hukuman atas dosa manusia. Pandangan ini didasarkan pada teks-teks Kitab Suci. Dalam Kitab Kej 3:1-24, Adam dan Hawa diusir dari taman Eden karena memakan buah terlarang. Inilah awal dosa dan penderitaan. Kedua, penderitaan merupakan ulah setan atau iblis untuk menjatuhkan manusia (bdk. Mat 15:22). Ketiga, penderitaan terjadi karena kebebasan manusia. ${ }^{2}$ Keempat, penderitaan ganjaran yang diberikan Allah untuk mendidik dan menguji iman manusia. Melalui penderitaan, Allah ingin menarik kembali jiwa-jiwa kepada-Nya. ${ }^{3}$

Tradisi iman kristiani justru berpegang pada keyakinannya bahwa Allah itu Maharahim, Mahakuasa dan Mahabaik. Dia menciptakan segala sesuatu "sungguh amat baik" (Kej 1:31). Walaupun demikian, inti iman ini dinilai bertentangan dengan realitas penderitaan yang dialami manusia. Apabila Allah menciptakan segala sesuatu baik adanya, mengapa ada penderitaan? Mengapa Allah membiarkan penderitaan merajam kehidupan manusia? Di manakah asal dan sumber penderitaan itu?

Aneka jawaban yang diberikan untuk menjelaskan misteri penderitaan yang dialami manusia dalam kehidupan ini ditanggapi dengan pikiran dan sikap yang berbeda. Di satu pihak, ada sejumlah manusia yang menerima penderitaan sebagai mediasi untuk mencapai kesempurnaan hidup. Sikap optimistis ini kerap dilukiskan dengan ungkapan: "tanpa penderitaan, hidup manusia tidak sempurna". Di pihak lain, kebanyakan manusia melihat penderitaan sebagai

2 Harold S. Kushner, Derita, Kutuk atau Rahmat: Manakala Kemalangan Menimpa Orang Saleh. Judul asli: When Bad Things Happen to Good People, diterjemahkan oleh A. Supratiknya (Jakarta: Kanisius, 1987), hlm. 100.

3 Felix Podimattam, "Why Would A Good God Allow Suffering", dalam Indian Theological Studies, vol. XLII, no. 2 (Juni 2005), hlm. 183. 
Alfonsus Ara,Kasih Yesus Kristus di Salib: Jawaban Tuntas atas Misteri ...

pengalaman yang merusak, mendatangkan kerugian (individu, sosial) dan menimbulkan krisis iman. ${ }^{4}$

Konsekuensi yang muncul dari pemahaman negatif terhadap penderitaan ini adalah munguatkan kecenderungan dalam diri manusia untuk menghindar dan melarikan diri darinya. Manusia mengalami ketidakpastian dan kehilangan pegangan hidup. Untuk menghadapi misterisitas dan kompleksitas penderitaan serta aneka persoalaannya, manusia berusaha mencari aneka metode dan alternatif, baik yang bersifat klinis maupun teoritis. Akan tetapi, usaha-usaha manusiawi ini justru berujung pada kebuntuhan sebab tidak memberikan jawaban yang tuntas atas pertanyaan manusia dan dambaanya untuk membebaskan diri dari belenggu penderitaan yang melilit kehidupan mereka.

Hal ini terjadi karena penderitaan manusia jauh lebih luas dan lebih kompleks dari sakit fisik yang dialami manusia. Situasi ini menyebabkan manusia beriman bersikap apatis terhadap Allah yang diimani. Berhadapan dengan sikap manusia ini, Paus Yohanes Paulus II dan Paus Benediktus menjawab pertanyaan manusia mengenai misteri penderitaan dalam dua dokumen penting, yaitu Surat Apostolik Salvifici Doloris dan Ensiklik Spe Salvi. Isi pemikiran yang diuraikan dalam kedua dokumen ini akan dirangkum dan dipaparkan dalam tulisan ini.

\section{Penderitaan dan Misterisitasnya menurut Surat Apostolik Salvifici Doloris dan Ensiklik Spe Salvi}

\section{Misteri Penderitaan dalam Perjanjian Lama dan Perjanjian Baru}

\section{Jawaban Perjanjian Lama}

Ketika mengalami penderitaan, satu pertanyaan yang muncul dari kedalaman batin kita adalah, "Mengapa ada penderitaan? Melalui pertanyaan ini, kita ingin menemukan alasan dan makna dari setiap bentuk penderitaan yang dialami sehingga penderitaan sungguhsungguh menjadi penderitaan yang bersifat manusiawi. ${ }^{5}$

\footnotetext{
${ }^{4}$ Fio Mascarenhas, "A Spirituality to Cope with Suffering", dalam Vidyajyoti, vol. 69, no. 10 (Oktober 2005), hlm. 734.

${ }^{5}$ Salvifici Doloris..., no. 7,8,9.
} 
Diakui bahwa pertanyaan mengenai adanya penderitaan sangat sulit dijawab sebab terkait erat dengan pertanyaan mengenai adanya kejahatan: "Mengapa ada kejahatan di dunia ini? Dalam arti tertentu, melalui pertanyaan mengenai adanya kejahatan tersirat pertanyaan mengenai adanya penderitaan. Pertanyaan ini juga sangat sulit dijawab sebab tidak ditujukan kepada dunia yang menjadi sumber kejahatan dan penderitaan, tetapi kepada Allah, Sang Pencipta dan Penguasa dunia ini. ${ }^{6}$

Pertanyaan seputar asal usul kejahatan dan penderitaan justru menjadi sumber kekecewaan dan konflik antara kita dengan Allah serta alasan untuk menyangkal keberadaan Allah. Kita mengakui bahwa adanya dunia ini sungguh-sungguh membuka mata dan hati kita untuk mengakui keberadaan Allah, Sang Pencipta. Kita mengakui bahwa Allah sungguh-sungguh ada: Dia Mahakuasa, Mahabesar, Mahabaik, Mahaagung dan Mahabijaksana. Namun adanya kejahatan dan penderitaan justru mengaburkan keberadaan-Nya sebagai Pencipta yang Mahabaik. ${ }^{7}$

Paus Yohanes Paulus II meyakinkan kita bahwa sikap kita terhadap Allah dan semua pertanyaan kita yang bernada gugatan terhadap-Nya didengar dan ditanggapi Allah sendiri. Tanggapan Allah dinyatakan dalam ungkapan yang hidup sebagaimana dikisahkan dalam Kitab Ayub. Ayub, orang yang saleh, tanpa kesalahan dicobai dengan aneka penderitaan. Dia kehilangan seluruh harta miliknya dan anak-anaknya. Dia juga ditimpah penyakit berat. Dalam keadaan yang mengerikan ini, tiga sahabatnya menjumpainya dan menyakinkannya dengan menggunakan logika Perjanjian Lama: "penderitaan bersumber dari kesalahan serius yang dilakukan manusia". ${ }^{8}$

Bagi ketiga sahabatnya, penderitaan yang dialami Ayub merupakan hukuman atas kejahatan yang dilakukannya. Ayub menderita karena "dia pasti telah melakukan suatu kesalahan yang sangat serius". Allah yang Mahaadil akan "membalas kebaikan dengan kebaikan dan membalas kejahatan dengan kejahatan". Allah tidak akan pernah menimpahkan penderitaan kepadanya apabila dia tidak berdosa. Bagi mereka, "penderitaan itu dikirim oleh Tuhan yang Mahaadil dan mendapatkan pembenarannya dalam tataran keadilan". Jika demikian

\footnotetext{
6 Salvifici Doloris..., no. 9.

7 Salvifici Doloris..., no. 9.

8 Salvifici Doloris..., no. 10.
} 
Alfonsus Ara,Kasih Yesus Kristus di Salib: Jawaban Tuntas atas Misteri ...

adanya logika Perjanjian Lama, maka patut ditegaskan bahwa hanya Allah sendirilah yang berkuasa atas hidup kita dalam keadaan apa pun dan hanya Dia sendirilah yang akan membalas kebaikan dengan kebaikan dan kejahatan dengan kejahatan. ${ }^{9}$

Tulisan-tulisan Perjanjian Lama melihat penderitaan sebagai hukuman Allah atas dosa-dosa kita, umat manusia. Allah adalah Pemberi Wahyu, Pencipta, Pemberi Hukum dan Hakim yang tidak tertandingi oleh kuasa duniawi. Karena itu, semua bentuk pelanggaran yang kita lakukan dengan penuh kesadaran dan kebebasan terhadap kebaikan Allah tidak hanya dilihat sebagai pelanggaran terhadap hukum, tetapi juga sebagai penghinaan kita terhadap Allah, Sang Pencipta dan Pemberi Hukum. Secara teologis, pelanggaran demikian (dilakukan secara bebas dan sadar terhadap kebaikan Allah) merupakan dosa. Allah, Hakim yang adil akan melimpahkan anugerah-Nya kepada orang yang baik dan menghukum orang yang jahat. Jalan-Nya lurus dan semua keputusan-Nya tepat sesuai dengan kebenaran dan keadilan-Nya (bdk. Ayb 4:8). ${ }^{10}$

Keyakinan para sahabat Ayub ini menegaskan bahwa penderitaan sungguh-sungguh merupakan hukuman atas dosa dalam tatanan keadilan. "Yang telah kulihat ialah bahwa orang yang membajak kejahatan dan menabur kesusahan, dia menuainya juga" (Ayb 1:9-11). Namun Ayub menantang keyakinan Perjanjian Lama yang menghubungkan penderitaan dengan hukuman atas dosa. Tantangan Ayub ini sungguh-sungguh lahir dari keyakinannya sendiri: Dia adalah orang yang saleh, jujur, takut akan Allah dan menjauhi kejahatan (Ayub $1: 1.8 ; 2: 3)$; dia tidak berdosa, tetapi penderitaan hebat justru merajam diri dan kehidupannya. Baginya, dia tidak pantas mendapat hukuman sebab dia tidak melakukan apa pun yang tidak berkenan di hadapan Allah. ${ }^{11}$

Pembelaan Ayub justru dilegitimasi oleh Allah sendiri. Allah mencela sahabat-sahabatnya yang mendakwa Ayub tanpa melihat sikap hidupnya yang sesungguhnya. Ayub tidak melanggar dasar-dasar moral yang transenden sehingga keadilan tidak harus ditegakkan kepadanya. Penderitaan tidak seharusnya dihubungkan dengan kesalahan yang dilakukan. Penderitaan Ayub adalah penderitaan orang

\footnotetext{
9 Salvifici Doloris..., no. 10.

10 Salvifici Doloris..., no. 10.

11 Salvifici Doloris..., no. 10,11.
} 
yang tidak bersalah: Ayub menderita bukan karena dosa-dosanya. Penderitaannya merupakan sebuah misteri yang tidak bisa dijelaskan dengan akal budi. Ayub tidak dihukum dan tidak ada alasan untuk menjatuhkan hukuman kepadanya, walaupun dia mengalami pencobaan yang sangat berat. Allah sendiri menghendaki adanya pencobaan itu atas diri Ayub untuk menguji ketulusan, kesucian dan ketaqwaan Ayub kepada-Nya. ${ }^{12}$

Berinspirasikan pada pengalaman Ayub ini, Paus Yohanes Paulus II menegaskan bahwa penderitaan hanya dilihat sebagai sebuah hukuman apabila dihubungkan dengan kesalahan yang dilakukan. Namun, tidaklah benar apabila semua penderitaan dilihat sebagai akibat dari kesalahan dan hukuman yang diberikan atas kesalahan yang dilakukan. ${ }^{13}$

Penegasan paus ini menunjukan bahwa tidak semua penderitaan manusia ditempatkan dalam tataran moral dan ditakar berdasarkan prinsip keadilan karena berakar pada dosa dan kejahatan yang dilakukan manusia. Paus juga menjelaskan bahwa dalam Perjanjian Lama, penderitaan tidak hanya dilihat sebagai hukuman atas dosa yang dilakukan, tetapi juga sebagai pendidikan yang diberikan Allah kepada Umat Pilihan-Nya agar mereka sungguh-sungguh mengalami belas kasih-Nya, memperbaiki diri dan bertobat. Dengan demikian, hukuman tidak dimaksudkan untuk membalas kejahatan obyektif atas dosa yang dilakukan, tetapi untuk membangun kembali kebaikan dalam diri manusia yang menderita. Penderitaan berfungsi "untuk membangun kembali kebaikan" dalam diri subyek yang menderita, "mengalahkan kejahatan" yang masih ada dalam diri manusia, "memperkuat kebaikan" dalam diri manusia dalam hubungannya dengan Allah dan sesama. ${ }^{14}$

Penderitaan dan misterisitasnya yang masih menyimpan segudang tanya dan teka-teka bagi manusia juga dilihat sebagai batu ujian bagi ketulusan, kesetiaan, kesucian dan ketaqwaan manusia kepada Allah. Penderitaan serentak menjadi momen berahmat bagi Allah untuk menyatakan hakekat diri-Nya sebagai Penguasa, Raja dan Jawaban Tunggal atas persoalan hidup. Penderitaan juga menjadi momen berahmat bagi manusia untuk menyadari ketergantungan

\footnotetext{
12 Salvifici Doloris..., no. 11.

13 Salvifici Doloris..., no. 11.

14 Salvifici Doloris..., no. 11.
} 
Alfonsus Ara,Kasih Yesus Kristus di Salib: Jawaban Tuntas atas Misteri ...

mutlaknya kepada Allah. Penderitaan menjadi jalan menuju pertobatan karena gerakan cinta dan belas kasih Allah serta membangun dan menghidupi kebaikan. Buah-buah rahmat ini merupakan kekuatan untuk bagi manusia untuk mengalahkan kejahatan dan dosa yang bertumbuh di dalam dirinya. ${ }^{15}$

\section{Jawaban Perjanjian Baru}

Dalam Perjanjian Baru, jawaban atas pertanyaan, "mengapa ada penderitaan?, ditemukan dalam pewahyuan mengenai Kasih Allah dalam diri Yesus Kristus. Kasih adalah sumber terkaya, penuh dan utuh untuk menjawab dan menjelaskan semua misteri penderitaan yang dialami manusia. Kasih Yesus Kristus yang tersalib adalah jawaban tuntas atas pertanyaan dan gugatan manusia terhadap Allah mengenai adanya penderitaan. Akan tetapi, jawaban itu hanya bisa ditemukan apabila manusia bersedia masuk ke dalam misteri penderitaan Yesus Kristus dan mengenakan penderitaan-Nya pada dirinya dengan penuh kasih. ${ }^{16}$

Keyakinan iman Gereja ini akan dimengerti apabila kita mengetahui dan memahami sumber penderitaan kita serta cara Yesus mengalahkan penderitaan kita. Paus Yohanes Paulus II menguraikan isi iman Gereja mengenai "kasih Yesus yang tersalib dan bangkit sebagai jawaban atas misteri penderitaan kita" dalam pokok-pokok pikiran iman di bawah ini:

\section{Sumber Penderitaan}

Hakikat Manusia: Makhluk Ciptaan yang Terbatas.

Paus Benediktus XVI menjawab aneka pertanyaan manusia mengenai misteri penderitaan dalam ensikliknya yang berjudul Spe Salvi (Harapan yang Menyelamatkan). Dalam dokumen ini, paus menjelaskan bahwa penderitaan tidak terpisahkan dari eksistensi manusia sebagai makhluk ciptaan Allah. Paus menjelaskan bahwa manusia adalah makhluk ciptaan Allah yang terbatas. Penderitaan merupakan cara unik

${ }^{15}$ Salvifici Doloris..., no. 11.

${ }^{16}$ Salvifici Doloris..., no. 13. 
untuk menyatakan kedalaman hakikat manusia sebagai "makhluk ciptaan Allah yang terbatas". ${ }^{17}$

Ini berarti bahwa penderitaan manusia itu sesungguhnya bersumber dari kodrat manusia sebagai makhluk ciptaan Allah yang terbatas. Diakui bahwa manusia adalah mahkota dari semua ciptaan. Manusia diciptakan menurut gambar dan rupa Allah sendiri. Manusia secitra dengan Allah, namun bukan Allah yang Mahakuasa dan Tidak Terbatas. Manusia memiliki keterbatasan sehingga membutuhkan Allah dan tergantung sepenuhnya kepada-Nya. ${ }^{18}$

Karena penderitaan itu bersumber dari kodrat manusia, maka penderitaan itu melekat, menyatu dan tidak akan pernah bisa dilenyapkan dari diri dan hidup manusia. Dengan cara yang khas, penderitaan mengajarkan manusia untuk menerima kodrat dirinya sebagai ciptaan yang terbatas serta berjuang menghadapi, mengatasi dan melampauinya. ${ }^{19}$ Apabila manusia sungguh-sungguh mengerti landasan ini, maka manusia akan mengerti bahwa penderitaan serentak memperlihatkan keterbatasan dan transendensinya dalam diri manusia sendiri. Manusia harus sadar dan yakin bahwa dalam kodratnya yang terbatas, Allah sudah menanamkan kemampuan dalam dirinya untuk melampaui dirinya sendiri: Manusia diciptakan sebagai makhluk yang terbatas, dipanggil dan diberdayakan oleh Allah untuk memasuki dan memahami misterisitas dirinya. Misteri penderitaan dan transendensinya dinyatakan dalam diri Yesus dan dalam cara-Nya menghadapi, menyikapi dan mengenakan penderitaan manusia pada diri-Nya. Misteri penderitaan manusia terjawab dan dikalahkan oleh penebusan Yesus Kristus melalui penderitaan-Nya di salib. Dia rela menderita karena cinta dan korban-Nya demi keselamatan manusia. ${ }^{20}$

17 Paus Benediktus XVI, Ensiklik Spe Salvi (Harapan yang Menyelamatkan (Seri Dokumen Gerejawi no. 88), diterjemahkan oleh Mgr. Hadisumarta, O.Carm \& Mgr. A.B. Sinaga, OFM Cap (Jakarta: Departemen Dokumentasi dan Penerangan KWI, 2014), no. 36. Untuk penulisan catatan kaki selanjutnya, dokumen ini akan disingkat Spe Salvi.

$$
\begin{aligned}
& 18 \text { Spe Salvi..., no. 36a. } \\
& 19 \text { Spe Salvi..., no. 36a. } \\
& 20 \text { Spe Salvi..., no. 36a. }
\end{aligned}
$$


Alfonsus Ara,Kasih Yesus Kristus di Salib: Jawaban Tuntas atas Misteri ...

Dosa

Paus Yohanes Paulus II menjelaskan bahwa penderitaan manusia juga bersumber dari dosa manusia sendiri. Dosa menggerakan manusia untuk melakukan kejahatan yang menjadi sumber penderitaan bagi manusia sendiri. ${ }^{21}$

Dalam Kitab Kejadian dilukiskan bahwa dosa bersumber dari diri manusia sendiri, yaitu salah mempergunakan kebebasan yang diberikan Allah kepadanya. Manusia melanggar aturan yang diberikan Allah untuk kepentingan dan kehidupannya sendiri. Allah melarang manusia untuk tidak memakan buah dari pohon yang tumbuh di tengah taman. Karena isi larangan tidak dijelaskan secara mendalam, maka ketika berhadapan dengan godaan yang bertentangan dengan larangan itu, manusia justru menentukan sikap yang tidak benar di hadapan Allah. Manusia mencurigai Allah: Jangan-jangan Allah memiliki strategi atau maksud jahat yang bisa merugikannya di balik larangan yang diberikan-Nya. Dalam kecurigaan itu, manusia pun melanggar perintah Allah. Manusia tidak menyadari bahwa dalam larangan itu terkandung ujian bagi kebebasannya serta peluang untuk digoda dan jatuh ke dalam dosa. ${ }^{22}$

Proses jatuhnya manusia ke dalam godaan dilukiskan dengan munculnya seekor ular. Sosok ular yang sesungguhnya sama sekali tidak melambangkan setan, tetapi memerankan suara batin manusia sendiri supaya pertentangan suara batin yang selalu menggerogoti manusia bisa disingkapkan. Karena suara ular dimengerti sebagai suara yang berbisik di kedalaman batin manusia, maka kita akan menemukan kenyataan yang umumnya dialami manusia. Apabila berhadapan dengan larangan atau batas yang menghalangi dan mengganggu kebebasan kita (beberapa kali terjadi), maka kita hanya melihat larangan itu sebagai penghalang yang mengekang kebebasan kita, tanpa bertanya dan tanpa mengerti maksud hakikinya. Akibatnya, kita merasa segala sesuatu yang ada serba dilarang dan terlarang. Ketika perasaan itu muncul dalam batin kita, maka pada saat itu juga bergejolak perasaan

${ }^{21}$ Salvifici Doloris..., no. 15.

${ }^{22}$ Gerhard Ludwig Muller, Dogmatica Cattolica: Per lo Studio e lla Prassi della Teologia (Milano: San Paolo, 1999), hlm. 173-180. 
yang tidak enak kepada Allah. Batin kita dihantui aneka bentuk pertanyaan, "Mengapa harus dilarang?23

Pertanyaan ini muncul karena manusia yakin bahwa Allah bermaksud jahat di balik larangan tersebut. Manusia merasa bahwa Allah menyembunyikan realitas yang terbaik bagi manusia, yaitu kejayaan yang akan digapai manusia di balik larangan tersebut. Kalau dimakan manusia tidak akan mati, tetapi justru akan memperoleh hidup dan menjadi serupa dengan Allah sendiri. Tergoda oleh keyakinannya ini, maka manusia pun mengambil dan memakan buah itu. Manusia jatuh ke dalam dosa. ${ }^{24}$

Setelah berbuat dosa, sikap manusia berubah terhadap Allah: manusia takut dan berlari untuk menyembunyikan diri. Belajar dari sikap manusia ini, maka satu fakta mendasar yang patut diperhatian: Dosa sama sekali tidak mengubah sikap Allah terhadap manusia, tetapi justru mengubah sikap dan kondisi manusia sendiri. "Allah tidak memarahi dan tidak menghukum manusia, tetapi manusia justru takut berhadapan dengan Allah. Manusia menutup diri terhadap belas kasih Allah untuk memberikan pengampunan serta mengurung diri dalam kedosaannya. Totalitas diri manusia terluka dan rusak akibat dosa". ${ }^{25}$

Hukuman yang diberikan Allah kepada manusia bukanlah ketetapan Allah, atau sesuatu yang berasal dari luar dan dikenakan kepada manusia, melainkan akibat langsung dari dosa itu sendiri. Allah sendiri dengan jelas mengatakan apa yang kelak dan harus terjadi atas diri manusia apabila mereka jatuh ke dalam dosa. ${ }^{26}$

Hal ini terjadi karena hukum Allah bukanlah undang-undang positif yang ditetapkan dalam wujud lahiriah. Hukum Allah adalah hakikat manusia sendiri: Allah memberikan hukuman-Nya dengan menciptakan manusia. Tatkala menciptakan manusia, Allah memberikan hakikat dan tujuan hidup. Inilah hukum Allah. Konsekuensinya, apabila

${ }^{23}$ Dianne Bergant, CSA - Robert J. Karris, OFM (ed), Tafsir Alkitab Perjanjian Lama (Yogyakarta: Penerbit Kanisius, 2002), hlm. 40-41.

${ }^{24}$ Dianne Bergant, CSA - Robert J. Karris, OFM (ed), Tafsir Alkitab Perjanjian Lama..., hlm. 40-41.

${ }^{25}$ Dianne Bergant, CSA - Robert J. Karris, OFM (ed), Tafsir Alkitab Perjanjian Lama..., hlm. 41.

${ }^{26}$ Dianne Bergant, CSA - Robert J. Karris, OFM (ed), Tafsir Alkitab Perjanjian Lama..., hlm. 41-41. 
Alfonsus Ara,Kasih Yesus Kristus di Salib: Jawaban Tuntas atas Misteri ...

manusia tidak hidup seturut hukum Allah (berdosa), maka dengan sendirinya manusia melawan hakikatnya sendiri sebab manusia menjalani hidup yang bertentangan dengan hakikat dan jati dirinya sendiri. Setiap perbuatan dosa ini akan merusak diri manusia sendiri serta membawa akibat negatif baginya. Inilah hukuman atas dosa manusia. ${ }^{27}$

Akibat hukuman ini, inti diri manusia menjadi rusak. Manusia mencurigai Allah sebagai sumber dan dasar hidup serta berjuang untuk menjamin dan mendasari kehidupannya atas kekuatannya sendiri. Manusia harus berjuang keras untuk mempertahankan hidupnya. Akan tetapi, semua perjuangannya terasa sia-sia sebab dalam kematian akan tampak jelas bahwa manusia tidak akan pernah sanggup menjamin semua usahanya di sepanjang kehidupannya. Manusia tidak akan pernah mampu menjamin kehidupannya sendiri sebab perjuangan manusia hanya menghasilkan semak duri. ${ }^{28}$

\section{Penderitaan Dikalahkan oleh Kasih}

Inti dari karya keselamatan Allah dalam diri Yesus Kristus adalah membebaskan manusia dari dosa dan kejahatan yang menjadi sumber penderitaan bagi manusia. Untuk membebaskan dan menyelamatkan manusia dari penderitaan, Allah "memberikan" Putera Tunggal-Nya untuk datang ke dunia. Kata "memberi" mengandung arti bahwa misi keselamatan Allah dinyatakan secara sempurna dalam penderitaan Putera-Nya. Allah rela menderita karena besarnya kasihNya kepada manusia. Kasih adalah daya hidup Allah yang membebaskan dan menyelamatkan manusia dari penderitaan. ${ }^{29}$

Dalam "kasih" Allah, manusia akan menemukan dan memahami cakupan makna fundamental dan definitif dari penderitaan itu sendiri. Karena kasih-Nya, Allah memberikan Putera-Nya yang Tunggal agar manusia tidak binasa, tetapi memperoleh hidup yang kekal dan memilikinya dalam kelimpahan. Manusia akan mengalami kebinasaan apabila kehilangan kehidupan kekal karena hidup dalam "keadaan terkutuk", mengembangkan kehidupan yang "ditolak oleh Allah" serta

${ }^{27}$ Dianne Bergant, CSA - Robert J. Karris, OFM (ed), Tafsir Alkitab Perjanjian Lama..., hlm. 42-43.

${ }^{28}$ Dianne Bergant, CSA - Robert J. Karris, OFM (ed), Tafsir Alkitab Perjanjian Lama..., hlm. 42-43.

29 Salvifici Doloris..., no. 14. 
tidak hidup dalam dan bersama Allah. Inilah penderitaan yang defenitif dalam kehidupan manusia. ${ }^{30}$

Paus menguraikan daya penebusan kasih Yesus untuk membebaskan dan menyelamatkan manusia dari belenggu dosa dan kejahatan dengan cara, yaitu: pertama, mengalahkan penderitaan dengan memasuki kehidupan manusia yang menderita; kedua, rela mengenakan dan memikul penderitaan manusia akibat dosa kejahatan manusia sendiri; ketiga, rela berkorban hingga wafat di kayu salib; keempat, kebangkitan-Nya mengalahkan dan menjawab misteri penderitaan manusia.

\section{Memasuki Kehidupan Manusia yang Menderita}

Manusia berusaha menghilangkan penderitaan yang merajam dirinya. Namun tiada seorang pun yang mampu menghilangkannya karena tiada seorang pun yang mampu menghilangkan keterbatasan manusiawi, kekuatan dosa dan kejahatan yang menjadi sumber penderitaan. Penderitaan hanya bisa dikalahkan oleh Allah dalam diri Yesus, Putra-Nya sendiri. Yesus memiliki cara yang unik dan radikal untuk mengalahkan penderitaan, yaitu dengan memasuki sejarah hidup manusia, menjadi manusia dan tinggal bersama manusia yang menderita. Dengan kekuatan Ilahi-Nya, Dia berkeliling sambil berbuat baik terhadap semua manusia, terutama terhadap orang-orang yang menderita dan membutuhkan pertolongan. Dia menyembuhkan orang sakit, menghibur orang yang berduka, memberi makan kepada orang lapar, menyembuhkan orang tuli, buta, kerasukan setan, orang kusta dan menghidupkan kembali orang mati. Hati-Nya mudah tergerak oleh belas kasihan melihat manusia yang mengalami penderitaan lahir dan batin akibat dosa dan kejahatan. ${ }^{31}$

Dengan kasih-Nya yang meluap, Yesus memasuki kehidupan manusia yang menderita akibat dosa dan kejahatan untuk menyelamatkan mereka. Karena alasan inilah, maka Paus Yohanes Paulus II menegaskan bahwa walaupun tidak semua penderitaan terikat dengan dosa (penderitaan Ayub, manusia yang saleh), namun akar kejahatan dan penderitaan yang menyebabkan manusia kehilangan kehidupan abadi bersama Allah adalah dosa. "Kejahatan dan penderitaan tetap terikat dengan dosa dan kematian". Penderitaan

30 Salvifici Doloris..., no. 14.

31 Salvifici Doloris..., no. 16; bdk. Spe Salvi..., no. 36. 
Alfonsus Ara,Kasih Yesus Kristus di Salib: Jawaban Tuntas atas Misteri ...

memiliki keterkaitan yang kompleks dengan dosa, terutama "dosa dunia", latar belakang kehidupannya yang penuh dosa (tindakantindakan pribadi) dan proses sosial dalam kehidupan manusia di dunia ini. ${ }^{32}$

Yesus, Putera Tunggal Allah hadir di dunia ini. Dia tinggal bersama manusia yang menderita untuk menyelamatkan mereka dari penderitaan yang definitif (eskatologi) akibat dosa dan kejahatan manusia sendiri. Dia menghancurkan akar-akar dosa dan kejahatan yang ada dalam diri manusia dan sejarah dunia dengan ketaatan-Nya yang menjadi sumber penderitaan hingga wafat di salib yang hina serta mengalahkan kematian dengan kebangkitan-Nya. ${ }^{33}$

\section{Mengenakan dan Memikul Penderitaan Manusia}

Yesus menyelamatkan manusia dari penderitaan bukan hanya dengan memasuki kehidupan manusia yang menderita, melainkan juga memikul dan mengenakan penderitaan manusia pada diri-Nya. "Lihatlah Dia meskipun tak bersalah, memikul di atas pundak-Nya kesengsaraan semua orang". ${ }^{34}$ Dia memasuki dunia manusia yang menderita dan mengenakan penderitaan manusia pada diri-Nya sendiri. Dia mengalami kelelahan fisik, disalah mengerti oleh orang-orang yang sangat dekat dengan-Nya, merasa terasing dan dikelilingi oleh orangorang yang memusuhi dan berusaha membunuh-Nya. Dia sadar akan kenyataan yang dihadapi-Nya dan berbicara mengenai kematian yang menanti-Nya di hadapan para murid-Nya. Dia pun menyongsong penderitaan dan kematiaan-Nya dengan penuh kesadaraan. Dia taat terhadap misi perutusan yang harus dipenuhi-Nya dengan cara demikian. ${ }^{35}$

Dengan memasuki dunia manusia yang menderita, mengenakan penderitaan manusia pada diri-Nya dan menyongsong penderitaan-Nya dengan rela, Yesus membebaskan manusia dari penderitaan dan kematian supaya manusia "tidak binasa, tetapi memiliki hidup yang kekal" ${ }^{36}$ Melalui penderitaan-Nya di salib, Dia menghancurkan akar-

\footnotetext{
32 Salvifici Doloris..., no. 15.

33 Salvifici Doloris..., no. 14.

${ }^{34}$ Salvifici Doloris..., no. $17 \mathrm{f}$.

${ }^{35}$ Salvifici Doloris..., no. 16c

${ }^{36}$ Yoh 3:16.
} 
akar dosa dan kejahatan dalam jiwa dan sejarah hidup manusia. Melalui salib-Nya, Dia menyelesaikan karya keselamatan-Nya bagi semua bangsa manusia. Melalui karya-Nya ini, Dia memenuhi rencana kasih Allah, yaitu menebus dosa, kejahatan, penderitaan dan kematian manusia. ${ }^{37}$

Tindakan Yesus ini sudah dinubuatkan oleh Nabi Yesaya dalam "Nyanyian Keempat Hamba Yahwe Yang Menderita" mengenai "penderitaan yang dialami seseorang yang akan diurapi oleh Allah di masa yang akan datang": 38

"Ia tidak tampan dan semaraknyapun tidak ada sehingga kita memandang dia, dan rupapun tidak sehingga kita menginginkannya. Ia dihina dan dihindari orang, seorang yang penuh kesengsaraan dan yang biasa menderita kesakitan; ia sangat dihina, sehingga orang menutup mukanya terhadap dia dan bagi kitapun dia tidak masuk hitungan. Tetapi sesungguhnya, penyakit kitalah yang ditanggungnya, dan kesengsaraan kita yang dipikulnya, padahal kita mengira dia kena tulah, dipukul dan ditindas Allah. Tetapi dia tertikap oleh karena pemberontakan kita, dia diremukan oleh karena kejahatan kita; ganjaran yang mendatangkan keselamatan bagi kita ditimpahkan kepadanya, dan oleh bilur-bilurnya kita menjadi sembuh. Kita sekalian sesat seperti domba, masing-masing kita mengambil jalannya sendiri, tetapi Tuhan telah menimpahkan kepadanya kejahatan kita sekalian."39

Nyanyian Hamba Yahwe Yang Menderita ini mengidentikan tahap-tahap penderitaan Kristus sebagai berikut: Dia ditahan, dihina, dipukul, diludahi, dihina, diadili, dicambuk, dimahkotai duri, diejek, memikul salib, disalibkan dan mengalami sakrat maut di kayu salib. Nyanyian ini juga menggambarkan dimensi terdalam dari pengurbanan Kristus. Dia tidak bersalah. Namun Dia harus memikul dosa, kejahatan dan penderitaan semua manusia. Dialah Hamba yang Menderita, "Anak Domba Allah yang menghapus dosa-dosa dunia". ${ }^{40}$

Allah meletakan semua beban dosa dan kejahatan manusia dalam keluasan dan kedalamannya di atas pundak-Nya. Dosa dan kejahatan manusia menjadi akar/sebab penderitaan Kristus, Hamba

\footnotetext{
37 Salvifici Doloris..., no. 16d.

38 Salvifici Doloris..., no. 17a.

${ }^{39}$ Yes 53:2-6.

40 Salvifici Doloris..., no. 17
} 
Alfonsus Ara,Kasih Yesus Kristus di Salib: Jawaban Tuntas atas Misteri ...

yang Menderita dan Sang Penebus. Dia menderita bukan karena dosa dan kejahatan-Nya sendiri, melainkan karena dosa dan kejahatan manusia. Penderitaan-Nya hanya "menggantikan", namun memiliki daya "keselamatan". Oleh penderitaan-Nya, dosa dan kejahatan manusia dihapuskan. Karena kedalaman dan kebesaran kasih-Nya, Dia rela meletakan dosa dan kejahatan manusia di pundak-Nya. Dia menerima, mengenakan dan menjalani-Nya dengan kasih yang utuh dan total kepada Bapa-Nya untuk mengalahkan kejahatan yang bersumber pada dosa manusia dan untuk menyelamatkan manusia. ${ }^{41}$

Kristus, Hamba Yahwe Yang Menderita rela menderita sebagai manusia, bersama dan untuk menyelamatkan manusia dari belenggu dosa dan kejahatan. Penderitaan-Nya memiliki sisi manusiawi dan historis yang unik serta memiliki kedalaman dan intensitas yang tidak bisa dibandingkan dengan penderitaan manusia. Penderitaan-Nya adalah penderitaan Putra Tunggal Allah, Allah dari Allah. Hanya Dialah Putra Tunggal Allah yang rela memikul tindakan kejahatan manusia akibat dosa: "dalam tiap dosa dan dalam dosa secara keseluruhan, menurut dimensi-dimensi eksistensi historis dari umat manusia di bumi ini". ${ }^{42}$

\section{Wafat dan Kebangkitan Yesus Kristus}

Kematian Hamba Yahwe di Kayu Salib.

Nubuat nabi Yesaya dalam "Nyanyian Hamba Yahwe yang menderita" terpenuhi secara sempurna dan definitif dalam diri Yesus. Nyanyian tersebut merupakan antisipasi profetis dari penderitaan Yesus di Taman Getsemani dan Puncak Kalvari. Yesus, Hamba Yahwe yang menderita rela memikul penderitaan manusia, walaupun Dia tidak berdosa. 43

"Dia dianiaya, tetapi Dia membiarkan diri ditindas dan tidak membuka mulutnya seperti anak domba yang dibawa ke pembantaian; seperti induk domba yang kelu di depan orang-orang yang menggunting bulunya, ia tidak membuka mulutnya. Sesudah penahanan dan penghukuman ia terambil, dan tentang nasibnya

\footnotetext{
${ }^{41}$ Salvifici Doloris..., no. 17

42 Salvifici Doloris..., no. 17

${ }^{43}$ Salvifici Doloris..., no. 18a
} 
siapakah yang memikirkannya? Sungguh ia terputus dari negeri orangorang hidup, dan karena pemberontakan umatKu ia kena tulah". ${ }^{44}$

Yesus menjawab pertanyaan mengenai misteri penderitaan manusia (dikisahkan dalam Kitab Ayub) dalam bentuk yang sangat radikal, yaitu melalui penderitaan-Nya sendiri. Dia menjawab pertanyaan itu, bukan dengan mengajukan pertanyaan yang sama ke dalam diri-Nya (mengapa Aku menderita?), bukan hanya dalam ajaranNya mengenai Kabar Baik, melainkan dalam "penderitaan-Nya sendiri". Dia mengintegrasikan ajaran-Nya mengenai Kabar Baik secara organis dan menyatakan isi ajaran-Nya itu dalam kerelaan-Nya untuk menderita di salib yang hina demi keselamatan manusia. Pengintegrasian ajaran dan kerelaan-Nya untuk menderita terpenuhi dalam Sabda Penderitaan-Nya dari Salib. Sabda Penderitaan merupakan Sabda terakhir dan definitif yang memiliki daya pembebasan dan penyelamatan bagi manusia. ${ }^{45}$

Dalam Sabda Penderitaan-Nya di salib, Yesus menyatakan bahwa penderitaan yang dijalani-Nya merupakan "kehendak Bapa demi keselamatan manusia". Titik yang sangat menentukan dalam menelusuri jalan penderitaan-Nya adalah doa-Nya di Taman Getsemani, "Ya BapaKu, jikalau sekiranya mungkin, biarlah cawan ini lalu daripadaKu, tetapi janganlah seperti yang Kukehendaki, melainkan seperti yang Engkau kehendaki"..."Ya BapaKu, jikalau cawan ini tidak mungkin lalu, kecuali apabila Aku meminumnya, jadilah kehendakMu". Doa Yesus ini serentak membuktikan kebenaran penderitaan yang dijalani-Nya serta kebenaran kasih-Nya karena ketaatan-Nya kepada Bapa-Nya. Doa Yesus ini juga membuktikan kebenaran tindakan Allah dalam penderitaan-Nya. Penderitaan yang dijalani-Nya adalah kebenaran sebab bersumber dan mengalir dari kasih-Nya. Kasih Allah adalah kebenaran sebab sungguh-sungguh dinyatakan dalam tindakanNya, yaitu rela memberikan diri-Nya di salib sebagai tebusan atas dosa dan kejahatan manusia. Kebenaran penderitaan-Nya bersumber dari kebenaran kasih-Nya. ${ }^{46}$

Doa Yesus di Taman Getsemani meneguhkan kebenaran dari penderitaan-Nya: Dia mengalami penderitaan karena dosa dan kejahatan yang menakutkan dan membinasakan manusia. Karena itu,

\footnotetext{
44 Yes 53:7-9.

${ }^{45}$ Salvifici Doloris..., no. 18b.

${ }^{46}$ Salvifici Doloris..., no. 18c.
} 
Alfonsus Ara,Kasih Yesus Kristus di Salib: Jawaban Tuntas atas Misteri ...

manusia selalu berdoa seperti yang didoakan Yesus di Taman Getsemani, "Semoga itu berlalu dari padaku". ${ }^{47}$ Doa Yesus juga membuktikan bahwa penderitaan yang ditanggung-Nya sungguh berat, mendalam, unik dan tidak terbandingkan. Penderitaan-Nya tidak sebanding dengan penderitaan kita dan tidak pernah dialami oleh siapa pun di antara kita, kecuali oleh diri-Nya sendiri. Kita hanya mampu memahami perbedaan antara penderitaan yang kita alami dengan penderitaan yang dialami oleh Allah-Manusia dalam diri Yesus apabila kita memasuki penderitaan-Nya Taman Getsemani: di taman inilah kita menemukan bahwa penderitaan-Nya sungguh-sungguh selaras dengan kebenaran yang dinyatakan Nabi Yesaya, yaitu penderitaan definitif yang diwahyukan Allah "di hadapan jiwa Kristus". 48

Doa Yesus di Taman Getsemani diteguhkan kembali dalam katakata-Nya di Puncak Kalvari. "Ya AllahKu, mengapa Engkau meninggalkan Aku? Kata-kata ini menjelaskan kepada kita mengenai dalam dan ganasnya dosa dan kejahatan dunia yang menyebabkan Dia menderita. Kata-kata ini juga muncul dari kesatuan yang tidak terpisahkan antara diri-Nya dengan Bapa-Nya. Jika Yesus satu, tidak terpisahkan dengan Bapa-Nya, "mengapa Bapa meletakan dan mengenakan dosa dan kejahatan kita kepada-Nya? ${ }^{49}$

Beban penderitaan yang ditanggung-Nya adalah beban dosa dan kejahatan kita: karena dosa dan kejahatan yang dilakukan, kita berpaling dari Allah dan meninggalkan Allah. Kita tidak sadar bahwa penderitaan yang paling mengerikan akibat dosa dan kejahatan kita adalah penolakan dan pemisahan diri kita dari Allah. Karena itu, dalam kata-kata-Nya di puncak salib, Yesus menyatakan kengerian dan ketakutan-Nya apabila kita sungguh-sungguh memisahkan diri dari Allah dan sesama. Karena ketakutan-Nya akan kengerian yang membinasakan akibat pemisahan diri kita dari Allah dan sesama, maka Dia menyelesaikan dan menyempurnakan misi penebusan-Nya melalui penderitaan-Nya. Dia rela menderita agar akar-akar dosa dan kejahatan yang memisahkan dan mengasingkan kita dari Allah dan sesama dikalahkan. Dia menghembuskan napas-Nya dan berkata, "Sudah selesai! ${ }^{50}$

\footnotetext{
47 Bdk. Mat 26:38-43.

48 Salvifici Doloris..., no. $18 \mathrm{~d}$.

49 Salvifici Doloris..., no. $18 \mathrm{e}$.

50 Salvifici Doloris..., no. 18e.
} 
Kenyataan ini menunjukkan bahwa semua penderitaan kita mencapai puncak kepenuhannya dalam penderitaan-Nya di salib. Yesus yang sungguh-sungguh menderita di Taman Getsemani dan Puncak Kalvari berseru kepada Allah, Bapa-Nya: Dia sudah mewartakan dan menyatakan keagungan kasih Bapa melalui misi pelayanan-Nya. Namun, Dia justru tidak dibebaskan dari kematian yang penuh penderitaan di salib yang hina. Penderitaan dan penebusan-Nya di salib merupakan pewahyuan terakhir, unggul, pasti dan definitif mengenai kekudusan, kesempurnaan, kemutlakan dan kepenuhan "keadilan" dan "cinta Allah" kepada manusia. "Dia yang tidak mengenal dosa telah dibuat-Nya menjadi dosa karena kita, supaya dalam Dia kita dibenarkan oleh Allah". Pernyataan ini menegaskan bahwa penderitaan di Taman Getsemani dan Puncak Kalvari merupakan kesaksian mengenai perlawanan kekuatan dosa dan kejahatan terhadap Putra Allah: Yesus, Putra Allah yang tidak bersalah dan tidak berdosa harus menderita karena kesalahan dan dosa kita. Dalam Dia, keadilan diberlakukan bagi dosa dan kejahatan. Dia harus membayar dengan harga pengurbananNya yang tiada taranya karena ketaatan-Nya kepada Bapa hingga wafat-Nya di kayu salib. ${ }^{51}$

Penderitaan dan kematian-Nya di salib yang lahir dari kebesaran dan keagungan kasih-Nya semata-mata untuk menciptakan kembali kebaikan antara Allah dengan kita dan kita dengan sesama. Penderitaan dan kematian-Nya di salib yang mengalirkan sungai-sungai kehidupan dan kesegaran bagi kita menyatakan kebenaran, kedalaman dan keradikalan kasih Allah dalam sejarah keselamatan kita. Di salib, Allah menyatakan kebesaran manusia karena memiliki Penyelamat yang Mahaagung serta memaklumkan kepada manusia bahwa kasih-Nya yang agung itu tidak akan mundur di hadapan pengurbanan Sang Putra. Di salib, Allah juga memenuhi kesetiaan-Nya sebagai Sang Pencipta dan Bapa bagi semua manusia, ciptaan yang secitra denganNya dan dipilih sejak awal mula dalam Putra-Nya demi rahmat dan kemuliaan. ${ }^{52}$

51 Paus Yohanes Paulus II, Ensiklik Dives in Miscericordia (Kaya dalam Kerahiman (Seri Dokumen Gerejawi no. 99), diterjemahkan oleh A. Alfons S. Suhardi, OFM \& B. F. Adisusanto, SJ (Jakarta: Departemen Dokumentasi dan Penerangan KWI, 2016), no. 7a,b,c. Untuk penulisan catatan kaki selanjutnya, dokumen ini akan disingkat Dives in Miscericordia.

52 Dives in Miscericordia..., no. 7a. 
Alfonsus Ara,Kasih Yesus Kristus di Salib: Jawaban Tuntas atas Misteri ...

Salib adalah penyataan yang penuh dan utuh mengenai keadilan dan kasih Allah. Keadilan Allah mengalir dari kasih-Nya dan terarah pada kasih itu sendiri. Dalam penderitaan Yesus di salib tampak bahwa Allah Bapa sungguh-sungguh tidak menyayangkan Putra-Nya sendiri untuk membenarkan kita. Bagi Allah, kebenaran dan keadilan-Nya yang berkelimpahan mutlak dinyatakan untuk menggantikan dan menebus dosa kita dengan pengurbanan-Nya. Keadilan Allah bersumber dari kasih-Nya dan berbuah kasih dalam pengurbanan-Nya sendiri. ${ }^{53}$

Keadilan Allah yang dinyatakan dalam salib Putra-Nya sungguh-sungguh sesuai dengan "ukuran Allah" karena mengalir dari kasih, memperoleh kepenuhannya dalam kasih dan menghasilkan buah keselamatan. Kasih dan tindakan belas kasih Yesus di salib mendasari keadilan, memberikan isi dan kandungan makna terdalam dari keadilan. Kasih dan belas kasih Yesus di salib merupakan nilai tertinggi dan teragung melebihi keadilan. Dengan demikian nyata bahwa dimensi penebusan Putra Allah terpenuhi bukan hanya dalam penegakan keadilan terhadap dosa dan kejahatan kita, melainkan juga dalam pewahyuan kasih dalam kepenuhannya kepada kita. ${ }^{54}$

\section{Kebangkitan: Mengalahkan Dosa dan Kematian.}

Kematian merupakan peristiwa pembebasan dari penderitaan di dunia ini dan akhir definitif dari penghancuran organisme jasmani dan rohani. Kematian memisahkan tubuh dari jiwa dan menghancurkan seluruh kepribadian manusia, baik jasmani maupun rohani. Tubuh secara perlahan akan mengalami kehancuran, sedangkan jiwa yang terpisah dari tubuh tetap hidup. ${ }^{55}$

Dalam konsep manusiawi, kematian bukanlah salah satu bentuk penderitaan. Namun, dalam arti tertentu, kematian sesungguhnya "melebihi semua bentuk penderitaan". Semua kejahatan dan penderitaan yang dialami manusia dalam kematian bersifat definitif dan menyeluruh. ${ }^{56}$

\footnotetext{
53 Dives in Miscericordia..., no. 8a.

54 Dives in Miscericordia..., no. 7c.

55 Salvifici Doloris..., no. 15b.

56 Salvifici Doloris..., no. 15b.
} 
Yesus, Hamba Yahwe yang Menderita mengalami kematian keji di kayu salib. Namun, Kematian-Nya bukanlah akhir dari kehidupanNya, bukanlah penghancuran tubuh-Nya yang kudus, bukan akhir dari misi-Nya dan bukan kata terakhir dari pesan dan misi mesianik-Nya. Yesus yang mengalami mati di salib justru "bangkit mulia" seperti yang dinyatakan-Nya di saat fajar kepada para wanita dan para Rasul datang ke makam-Nya. Pada saat itulah, mereka mendengar pesan mesianikNya bahwa "Dia telah bangkit". ${ }^{57}$

Dalam terang salib dan kebangkitan inilah penderitaan dan kemuliaan Yesus di salib memperlihatkan corak injili-Nya: kebangkitanNya memanifestasikan kemuliaan salib-Nya sebab di salib yang hina, Dia dimuliakan. Salib serantak menyatakan pengosongan dan pengangkatan diri-Nya. Di salib, Dia memenuhi dan menyempurnakan misi perutusan-Nya serta merealisasikan diri-Nya dalam wujud yang penuh dan utuh. Dalam kelemahan salib, Dia menyatakan kekuatan ilahi-Nya. Dalam kehinaan salib, Dia menyatakan keagungan dan kemuliaan mesianik-Nya. Dia sungguh-sungguh Mesias, Penyelamat manusia. Perkataan-Nya yang terungkap di salib membuktikan keagungan dan kemuliaan diri-Nya sebagai Mesias: Dia bukanlah Allah yang menghukum dan membinasakan, melainkan Sang Mesias Cinta yang merangkul dan memberikan kehidupan melalui pengampuan-Nya yang tanpa batas. "Ya Bapa ampunilah mereka, sebab mereka tidak tahu apa yang mereka perbuat". 58

Berkat kebangkitan-Nya, Dia menyatakan diri-Nya sebagai Jaminan Tunggal bagi keselamatan dan kebangkitan badan semua orang yang percaya kepada-Nya di masa yang akan datang. Daya kematian dan kebangkitan-Nya yang menebus dosa dan mengalahkan kuasa kematian ini menjadi syarat mutlak untuk kehidupan kekal. Kita hanya memperoleh kebahagiaan yang definitif berkat daya penebusan Yesus dan berkat kesatuaan kita dengan Yesus, Sang Penebus. Berkat daya penebusan-Nya, dalam perspektif esktologis, penderitaan kita sungguhsungguh dikalahkan. ${ }^{59}$

Daya kebangkitan-Nya membawa kita kepada harapan akan kehidupan kekal dan kekudusan. Walaupun demikian, kemenanganNya atas dosa dan kematian melalui kematian dan kebangkitan-Nya

\footnotetext{
57 Dives in Miscericordia..., no. $7 \mathrm{~g}$.

58 Salvifici Doloris..., no. 22b.

${ }^{59}$ Salvifici Doloris..., no. 15c.
} 
Alfonsus Ara,Kasih Yesus Kristus di Salib: Jawaban Tuntas atas Misteri ...

yang mulia tidak menghapus penderitaan sementara dari kehidupan kita dan tidak membebaskan semua dimensi sejarah kehidupan kita dari penderitaan. Akan tetapi, kemenangan-Nya justru memancarkan sinar baru terhadap dimensi penderitaan, dosa dan kematian. KemenanganNya melalui kebangkitan-Nya memancarkan cahaya keselamatan bagi semua bentuk penderitaan. Inilah cahaya Injil, Kabar Baik. Dalam terang Kabar Baik inilah, dunia yang penuh penderitaan menemukan kebenaran yang dinyatakan dalam percakapan-Nya dengan Nikodemus, "Karena begitu besar kasih Allah sehingga Dia telah mengaruniakan Putera-Nya yang Tunggal" ${ }^{60}$

Inti kebenaran Kabar Baik ini secara radikal mengubah gambaran mengenai sejarah kehidupan kita dan keadaan kita di dunia ini: walaupun dosa sungguh-sungguh berakar dalam sejarah hidup kita, namun kasih Allah melampaui kekuatan dosa dan kejahatan. Allah sungguh-sungguh mengasihi Putra Tunggal-Nya hingga kesudahannya. Kasih Allah melampaui batas: Dia memberikan Putra-Nya sendiri untuk menghapus akar-akar kejahatan kita. Berkat daya penyelamatan-Nya, Dia menutup semua dunia penderitaan yang menjadi bagian dari kehidupan kita. ${ }^{61}$

Walaupun demikian, pemuliaan Yesus yang tersalib melalui kebangkitan-Nya sama sekali tidak meniadakan salib dari kehidupan kita. Salib "tetap" dan "selalu ada", yaitu "salib yang memberikan kesaksian mesianik mengenai Putra Manusia yang rela menderita dan wafat demi keselamatan kita". Dalam salib Putra-Nya, Allah tidak pernah berhenti berbicara mengenai kasih-Nya yang kekal kepada kita. Kasih-Nya selalu hadir di dunia, dilimpahkan-Nya kepada dunia dan selalu lebih kuat dari semua dosa dan kejahatan yang ada dalam diri kita dan dunia. Percaya kepada kasih Allah yang kekal dalam diri PutraNya yang tersalib dan bangkit berarti percaya pada belas kasih-Nya sebab belas kasih adalah dimensi kasih yang mutlak ada untuk menyatakan kasih-Nya ketika berhadapan dengan dosa dan kejahatan yang membelenggu kehidupan kita. ${ }^{62}$

Kebangkitan-Nya merupakan puncak pewahyuan dan perwujudan kasih-Nya kepada kita. Berkat kebangkitan-Nya, kita dibenarkan, keadilan dipulihkan dan tata keselamatan yang

\footnotetext{
${ }^{60}$ Salvifici Doloris..., no. 15d.

${ }^{61}$ Salvifici Doloris..., no. 15d.

62 Dives in Miscericordia..., no. $7 \mathrm{~g}$.
} 
dikehendaki-Nya sejak awal penciptaan terpenuhi dalam diri kita dan melalui diri kita yang dibenarkan, dipulihkan dan diselamatkan akan tercipta kebenaran, keadilan dan kebaikan dalam dunia. KebangkitanNya menyatakan bahwa salib di Puncak Kalvari lahir dari intisari kasih yang dianugerahkan-Nya kepada kita sebagai makhluk istimewa yang diciptakan menurut gambar dan rupa-Nya sendiri dan sesuai dengan rencana-Nya yang kekal. Pewahyuan Allah dalam diri-Nya sebagai Sang Pencipta dan sumber utama eksistensi diri kita tidak hanya terhubung dengan dunia, tetapi juga dihubungkan dengan diri kita yang dipanggil-Nya untuk berada di dunia melalui ikatan yang lebih intim dan mendalam daripada ikatan-Nya dengan dunia. Kasih-Nya tidak hanya mendatangkan kebaikan, tetapi juga memberdayakan kita untuk ambil bagian dalam kehidupan-Nya sendiri. ${ }^{63}$

Kebangkitan-Nya menegaskan kepada kita bahwa penderitaan dan kematian-Nya di salib merupakan jalan silih atau pertukaran yang mengagumkan dengan dosa dan kejahatan kita. Melalui kebangkitanNya, Allah mengomunikasikan kepada kita jalan panggilan kita untuk ambil bagian dalam kehidupan, kebenaran dan kasih yang ada dan mengalir dari hidup-Nya sendiri. Kebangkitan-Nya mengubah sejarah penderitaan kita menjadi jalan pemilihan kekal sebagai anak-anak Allah. Dalam sejarah salib Dia yang bangkit dinyatakan kesaksian final mengenai perjanjian indah antara Allah dengan kita, manusia ciptaanNya. Isi perjanjian itu adalah: berkat penderitaan, salib dan kebangkitanNya, Putra Tunggal Allah menjadi "terang dari terang, Allah benar dari Allah benar" bagi kita. Isi perjanjian yang seusia dengan sejarah hidup kita ini senantiasa diperbaharui sebagai perjanjian yang baru dan definitif. Perjanjian ini diikat di Kalvari dan terbuka bagi semua bangsa manusia. ${ }^{64}$

Dia yang tersalib dan bangkit menyatakan kepada kita kebenaran tindakan Allah yang rela merendahkan diri-Nya justru di saat-sat yang paling sulit dan menyakitkan, yaitu saat-saat yang dipandang sebagai takdir yang sangat tidak menyenangkan dalam kehidupan kita. Dia yang bangkit menyatakan bahwa salib-Nya merupakan sentuhan kasih-Nya yang abadi tehadap luka yang paling dalam dan menyakitkan dalam kehidupan kita. Kebangkitan-Nya menyatakan bahwa penderitaan dan kematian-Nya di salib merupakan pemenuhan total dan definitif dari program mesianik-Nya yang

${ }^{63}$ Dives in Miscericordia..., no. 7d.

${ }^{64}$ Dives in Miscericordia..., no. 7f. 
Alfonsus Ara,Kasih Yesus Kristus di Salib: Jawaban Tuntas atas Misteri ...

disampaikan-Nya di Sinagoga Nazaret, yaitu pewahyuan kasih yang penuh belas kasih kepada kaum papa miskin, orang yang menderita, para tahanan, orang buta, orang yang tertindas dan orang yang berdosa. Daya kebangkitan-Nya menuntun kita untuk mengerti bahwa akar dari penderitaan dan kematian kita adalah dosa dan kejahatan kita sendiri. Dengan demikian, salib Dia yang bangkit menjadi tanda eskatologis. Artinya, hanya dalam pemenuhan eskatologis dan pembaharuan definitif dunia ini, kasih sungguh-sungguh mengalahkan sumber terdalam dari penderitaan kita dan menghasilkan kerajaan kehidupan, kekudusan dan kekekalan yang mulia. Dasar pemenuhan eskatologis ini sudah dirangkum dalam salib dan kematian-Nya. Kenyataan bahwa Yesus bangkit pada hari ketiga menjadi tanda terakhir perutusan mesianik-Nya. Tanda ini menyempurnakan semua pewahyuan kasih yang berbelas kasih di hadapan kita dan dunia yang tunduk kepada dosa dan kejahatan. Pada saat inilah akan tercipta langit dan bumi yang baru. Allah akan menghapus semua air mata kita karena beban penderitaan. Maut, perkabungan, ratap tangis dan dukacita tidak ada lagi sebab yang lama sudah berlalu. ${ }^{65}$

Dalam kegenapan eskatologi, kasih dinyatakan sebagai kasih, sedangkan dalam kehidupan manusia yang penuh penderitaan akibat dosa dan kejahatan, kasih dinyatakan dalam wajah belas kasih dan diwujudkan dalam tindakan yang berbelas kasih. Program mesianik Yesus harus menjadi program Gereja, program kita angotan Gereja. Salib Yesus yang bangkit harus menjadi pusat karena salib adalah puncak pewahyuan cinta yang berbelas kasih dari Dia yang bangkit. Melalui salib Yesus yang bangkit, Allah menyatakan keagungan kasihNya serta mengundang kita untuk berbelas kasih bersama Putra-Nya yang Disalibkan. ${ }^{66}$

Dia yang tersalib dan bangkit adalah Kristus yang sabda-Nya tidak akan berlalu. Dia selalu berdiri di depan pintu dan mengetuk pintu hati kita untuk menimbah air kasih dari kasih-Nya yang berbelas kasih, membebaskan dan menyelamatkan. Dia mengundang kita untuk menimbah air kasih-Nya, bukan sebagai wujud solidaritas kita terhadap penderitaan-Nya, melainkan sebagai wujud belas kasih kita kepadaNya. Dia menghendaki agar kita sadar bahwa dalam seluruh pewahyuan kasih dan belas kasih-Nya di salib, Dia memberikan penghargaan dan penghormatan yang tinggi terhadap martabat

${ }^{65}$ Dives in Miscericordia..., no. 8a.

${ }^{66}$ Dives in Miscericordia..., no. 8b. 
manusiawi kita. Melalui pewahyuan kasih dan belas kasih-Nya di salib, Dia juga menghendaki agar hati kita mudah tergerak oleh belas kasih, mampu berbelas kasih serta saling menaruh belas kasih karena Dia sudah menunjukkan kasih dan belas kasih-Nya kepada kita. "Sesungguhnya segala sesuatu yang kamu lakukan untuk salah seorang saudaraKu yang paling hina ini, kamu telah melakukannya untuk Aku". Inilah inti dari seluruh Kabar Baik dan pertukaran yang mengagumkan antara dosa dan kejahatan kita dengan kematian-Nya di salib karena kasih dan belas kasih-Nya kepada kita! Pertukaran merupakan rencana Allah untuk keselamatan kita. Inti pertukaran yang lahir dari kasih yang berbelas kasih menjadi sebuah hukum yang sederhana, namun serentak kuat dan lembut. ${ }^{67}$

\section{Sikap Manusia Menghadapi Penderitaan}

Menerima dan Menghadapi Penderitaan.

Patut diakui bahwa dengan kemajuan pesat yang dicapai dalam dunia medis saat ini, kita bukan hanya memerangi dan mengakhiri penderitaan fisik dari kehidupan kita, melainkan juga berjuang untuk membangun kehidupan duniawi tanpa penderitaan. Apakah perjuangan ini akan terwujud? Kita tidak sadar bahwa di saat kita berjuang untuk membangun kehidupan tanpa penderitaan, sesungguhnya kita sudah menyangkal kemanusiaan kita. Kita tidak berbesar hati menerima dan mengakui keterbatasan manusiawi kita. Kita tidak mengakui bahwa sampai kapan pun penderitaan tidak akan pernah menghilang dari kehidupan kita karena penderitaan itu menyatu dengan kodrat kemanusiaan kita. 68

Kita harus sadar dan mengakui bahwa tidak ada kehidupan tanpa penderitaan. Dalam sekejap, kita mungkin bisa menghindar, namun tidak akan pernah luput dari penderitaan. Penderitaan adalah bagian dari hidup yang harus ditanggung, walaupun dengan perasaan takut dan cemas, sebab penderitaan itu berasal dari kodrat kemanusiaan kita yang terbatas. Paus Benediktus XVI menegaskan bahwa dengan cara apa pun, kita tidak akan pernah mampu menghilangkan penderitaan dari diri dan kehidupan kita di dunia ini. Penderitaan tidak akan bisa dilenyapkan karena tiada seorang pun yang mampu

${ }^{67}$ Dives in Miscericordia..., no. 8b.

${ }^{68}$ Spe Salvi..., no. 36a. 
Alfonsus Ara,Kasih Yesus Kristus di Salib: Jawaban Tuntas atas Misteri ...

menghilangkan keterbatasan manusiawi kita, kekuatan dosa dan kejahatan yang menjadi sumber penderitaan kita. Penderitaan hanya bisa dikalahkan oleh Allah sendiri. ${ }^{69}$

Paus Benediktus XVI mengingatkan kita bahwa apabila kita masih berjuang untuk mengakhiri penderitaan dengan cara menghindar dari segala sesuatu yang mendatangkan rasa sakit serta menjauhkan diri dari semua bentuk penderitaan dan kesulitan, maka kita akan memasuki alam kehidupan yang kosong dan kehidupan tanpa makna. Paus mengakui bahwa ketika kita berusaha menghindar dari penderitaan, kita tidak akan merasakan penderitaan itu, namun kita akan mengalami perasaan gelap tanpa makna. Kita juga merasa ditinggalkan sebab penderitaan itu menyatu dengan kodrat kemanusiaan kita. ${ }^{70}$

Paus Benediktus XVI menjelaskan bahwa Yesus hadir di salib bukan untuk mengakhiri dan melenyapkan penderitaan dari sejarah kehidupan kita. Dia hadir di salib untuk mengajarkan kita bagaimana seharusnya menghadapi dan mengalahkan penderitaan. Salib Yesus di Jumat Agung mengajarkan kita untuk berani menghadapi penderitaan dan Allah dalam diri Yesus turut menanggungnya. Di sini kita melihat besarnya cinta Yesus kepada kita. Dia menunjukkan kepada kita bahwa mencintai seseorang, bukan berarti melenyapkan penderitaannya, melainkan turut merasakan dan menanggungnya. Inilah yang dilakukan Yesus kepada kita. Satu jawaban yang walaupun tidak logis di mata kita, namun sangat membantu kita untuk menyikapi dan mengatasi penderitaan dalam kehidupan kita. ${ }^{71}$

Penderitaan adalah bagian hidup yang harus ditanggung, walaupun dengan perasaan takut dan cemas, sebab penderitaan itu berasal dari kodrat kemanusiaan kita yang terbatas. Penderitaan bisa dikalahkan, bukan dengan cara "menghindari penderitaan, atau "menyingkir dari penderitaan", melainkan "dengan kemampuan menerimannya". Apabila kita berjuang untuk menerima setiap bentuk penderitaan dalam kehidupan kita, maka kita akan dimatangkan oleh penderitaan dan menemukan makna dari setiap penderitaan yang dialami dalam kehidupan kita berkat persatuan kita dengan Yesus Kristus yang menderita karena kasih dan memiliki kasih tanpa batas. ${ }^{72}$

\footnotetext{
${ }^{69}$ Spe Salvi..., no. 36a.

70 Spe Salvi..., no. 37.

${ }^{71}$ Dives in Miscericordia..., no. 7a,b,c.

72 Spe Salvi..., no. 37.
} 
Penderitaan selalu menakutkan dan tidak tertahankan. Namun, dalam diri Yesus yang rela menderita karena kasih terbitlah bintang harapan, jangkar hati yang mencapai takhta Allah. Yang jahat tidak akan dilenyapkan dari diri kita, namun cahaya kasih Dia yang rela menderita dan bangkit selalu menang. Penderitaan tidak akan pernah berhenti menjadi penderitaan. Kasih Dia yang menderita dan bangkit menyatakan kecemerlangan-Nya sehingga kita diajarkan untuk mampu memadahkan pujian dalam setiap penderitaan kita. ${ }^{73}$

\section{Ambil Bagian dalam Penderitaan Kristus}

Penderitaan dan kebangkitan Yesus Kristus membawa kita ke dalam situasi baru dan hidup dalam situasi baru. Yesus yang menderita itu bangkit dan hidup. Karena penderitaan dan kebangkitan-Nya, kita semua ditebus dan memiliki bagian dalam kebangkitan dan kehidupanNya sebagai pribadi yang ditebus. Kita dipanggil untuk ambil bagian dalam penderitaan-Nya dan belajar bagaimana caranya menghadapi setiap penderitaan. ${ }^{74}$

Yesus Kristus menghadapi dan mengalahkan penderitaan dengan cara-Nya yang unik dan radikal. Dia tidak menghindar atau melarikan diri dari penderitaan, melainkan "masuk ke dalam kehidupan kita yang penuh penderitaan, ambil bagian dalam penderitaan kita, mengenakan penderitaan kita pada diri-Nya sendiri serta menebus penderitaan dan kematian kita dengan penderitaan dan kematian-Nya sendiri". Penderitaan dan kematian tidak mengakhiri dan tidak menghancurkan hidup-Nya yang agung. Dia yang rela menderita karena kasih-Nya kepada kita justru bangkit mulia. Dalam kebangkitanNya, kita menemukan cahaya yang sama sekali baru, yaitu cahaya yang menuntun kita untuk berani menghadapi keraguan, keputusasaan dan ketakutan dalam menghadapi penderitaan. ${ }^{75}$

Tuntutan iman agar kita ambil bagian dalam penderitaan Yesus dan mengikuti cara-Nya menghadapi penderitaan memiliki dua landasan hakiki:

Pertama, kemampuan kita untuk ambil bagian dalam penderitaan Yesus Kristus semata-mata karena Yesus Kristus sendiri sudah

\footnotetext{
${ }^{73}$ Spe Salvi..., no. 37.

${ }^{74}$ Salvifici Doloris..., no. 19b.

75 Salvifici Doloris..., no. 16a,b,c;
} 
Alfonsus Ara,Kasih Yesus Kristus di Salib: Jawaban Tuntas atas Misteri ...

membuka penderitaan-Nya untuk kita, ambil bagian dalam penderitaan kita dan mengenakan penderitaan kita pada diri-Nya sendiri. ${ }^{76}$

Kedua, apabila kita mampu memahami dan mengakui isi iman bahwa melalui penderitaan-Nya, Yesus sungguh-sungguh menebus dan menyelamatkan kita dari penderitaan akibat keterbatasan manusiawi dan dosa-dosa kita, maka kita akan menerima bahwa dalam penderitaan Yesus, sesungguhnya kita menemukan penderitaan kita sendiri: Penderitaan Yesus adalah penderitaan kita. Dalam penderitaan-Nya, arti dan isi penderitaan kita diubah dan diperkaya menjadi arti dan isi yang baru, sehingga seperti Yesus sendiri, kita akan menerima dan menghadapi setiap penderitan dengan "kasih" sebagaima "kasih sudah membawa Yesus Kristus ke puncak salib". ${ }^{77}$

Yesus hidup dalam diri kita. Dia mengenakan dan menjadikan penderitaan kita sebagai penderitaan-Nya sendiri. Apabila kita hidup dalam Dia, maka kemanusiaan kita akan dipersatukan dengan Dia dan salib-Nya. Karena Yesus dimuliakan dalam salib-Nya, maka kita akan bermegah dalam salib Dia yang tersalib dan bangkit. ${ }^{78}$

Salib Yesus yang bangkit memancarkan cahaya yang menyelamatkan. Salib-Nya menyentuh perasaan, kehidupan dan penderitaan kita. Salib dan kebangkitan-Nya menjangkau dan merangkum kemanusiaan kita. Dalam penderitaan kita terkandung misteri kebangkitan kita sendiri. Namun, kemuliaan kebangkitan akan dialami apabila kita ambil bagian dalam penderitaan-Nya dengan menelusuri jalan penderitaan kita serta memikul salib kita dengan penuh cinta. ${ }^{79}$

\section{Menderita Bersama Orang Lain}

Pada hakikatnya, kesejatian kita sebagai manusia ditentukan oleh kemampuan kita untuk melihat dan menghubungkan penderitaan kita dengan penderitaan orang lain, baik pribadi maupun kelompok masyarakat yang berada di sekitar kita. Kita akan menjadi pribadi yang kejam apabila tidak menerima penderitaan orang lain dan tidak bersedia

\footnotetext{
76 Salvifici Doloris..., no. 20d.

77 Salvifici Doloris..., no. 20d\&e.

78 Salvifici Doloris..., no. 20e.

${ }^{79}$ Salvifici Doloris..., no. 21.
} 
menanggung penderitaan bersama mereka. Sikap demikian akan terpupuk apabila kita tidak memahami arti penderitaan sebagai jalan menuju pemurnian, pendewasaan dan pengharapan. ${ }^{80}$

Kita akan mampu menerima penderitaan orang lain apabila kita melihat dan menerima penderitaan orang lain sebagai penderitaan kita sendiri. Jika sikap demikian terbangun dan dimiliki, maka setiap penderitaan yang dialami akan memancarkan cahaya dan makna baru sebab ditanggung bersama dengan orang-orang yang menderita. Keutamaan ini hanya terbentuk apabila kita memiliki "kasih" kepada orang-orang yang menderita: karena kasih, penderitaan akan ditanggung bersama. Karena kasih, penderitaan akan menjadi penderitaan bersama (milik bersama). Penderitaan bersama yang lahir dan ditanggung bersama karena kasih terhadap orang lain menyiratkan kerelaan untuk berada bersama dengan orang yang menderita. ${ }^{81}$

Menurut Paus Yohanes Paulus II, kerelaan untuk berada bersama, ambil bagian dalam penderitaan orang lain dan rela menderitaan bagi orang lain lahir dari kebesaran moral atau kematangan rohani seseorang. Keutamaan ini nyata dalam kerelaan para martir dan para saksi iman Kristus serta orang-orang yang tidak percaya kepada Kristus. Mereka rela menderita karena iman dan kasih mereka kepada Kristus serta rela memberikan hidup mereka untuk memperjuangkan kebenaran dan keadilan karena kasih kepada yang lain. Dalam penderitaan yang dialami, martabat manusiawi mereka yang agung diteguhkan. 82

Menurut Paus Benediktus XVI, kerelaan untuk menderita bersama orang lain karena kasih dan demi kasih terhadap orang lain akan berarti apabila dimotivasi oleh keinginan untuk menciptakan kebenaran dan keadilan demi kebaikan bersama. Kerelaan untuk menderita bersama dan untuk orang lain merupakan takaran dan tuntutan hakiki dari kemanusiaan kita. ${ }^{83}$

Paus Benediktus XVI menyadarkan kita bahwa akar penderitaan dalam kehidupan pribadi dan bersama sesungguhnya bersumber dari ego diri yang tinggi untuk mengutamakan kemakmuran dan

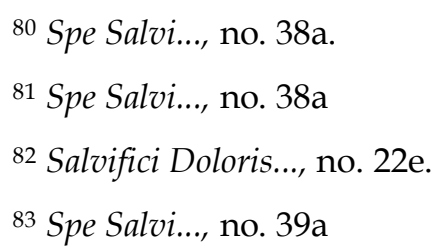


Alfonsus Ara,Kasih Yesus Kristus di Salib: Jawaban Tuntas atas Misteri ...

keselamatan diri daripada kebenaran, keadilan dan kebaikan bersama. Apabila ego diri menguat, maka kekuasaan akan meraja, kekerasan dan penipuan akan merajalela. Namun, sebagai pengikut Kristus, kita harus memperjuangkan dan mengutamakan kebenaran dan keadilan daripada kenyamanan dan kesejahteraan fisik kita sendiri. Fiat kita terhadap kasih bagi orang lain harus dibayar mahal sebab akan menjadi sumber penderitaan bagi kita. Kasih yang murni menuntut kita untuk berani menyangkal diri serta rela memberikan diri diri kita untuk "dipotong dan dilukai." Tiada kasih tanpa penyangkalan diri. Kasih tanpa penyangkalan diri hanyalah sebuah bentuk egoisme murni. Pada tataran ini, kasih berhenti menjadi kasih. ${ }^{84}$

Apabila kita rela menderita bersama dan untuk orang lain karena kasih, kita akan menjadi pribadi yang pengasih. Inilah dimensi fundamental dari kemanusiaan kita: rela menghancurkan kemanusiaan kita sendiri karena kasih, demi kebaikan orang lain yang dikasihi. Paus Benediktus XVI mengakui bahwa bagi kaum kristiani, perjuangan untuk membela kebenaran dan keadilan karena kasih bukanlah cita-cita semata, melainkan juga sebagai tuntutan iman yang sangat sulit diwujudkan. Walaupun demikian, kita harus mengikuti teladan kasih Allah, Sang Kebenaran dan Kasih. Dia rela menderita bersama dan untuk kita karena besarnya kasih-Nya kepada kita. ${ }^{85}$

Paus Benediktus XVI menegaskan keyakinan iman Gereja mengenai kebesaran kasih Allah yang rela menderita bersama dan untuk kita dengan mengutip perkataan Bernardus dari Clairvaux: Impassibilis est Deus, sed non incompassibilis (Allah tidak bisa menderita, tetapi Dia bisa ikut menderita). Allah rela menjadi manusia agar bisa menderita bersama kita dalam daging dan darah karena kita sungguhsungguh berharga di hadapan-Nya. Karena itu, Dia menghendaki agar kita juga rela menderita bersama dan untuk orang lain yang menderita karena kasih kita kepada Allah dan sesama. Apabila kita rela menderita bersama dan untuk orang lain, kita menyatukan semua penderitaan kita dengan orang-orang yang menderita. Kita menanggung penderitaan bersama mereka dan hadir dalam penderitaan mereka untuk menyatakan kasih Allah yang penuh bela rasa. Penderitaan yang ditanggung bersama akan menerbitkan bintang harapan. Harapan itu nyata dalam kunjungan persaudaraan. Orang yang menderita akan

\footnotetext{
84 Spe Salvi..., no. 39a.

85 Spe Salvi..., no. 39a.
} 
menemukan jalan keluar dan luka-luka mereka akan disembuhkan berkat kehadiran kita. 86

Paus Yohanes Paulus II dengan penuh keyakinan berkata bahwa kehadiran dan kerelaan kita untuk menderita bersama dan untuk orangorang yang menderita merupakan tanda nyata keikutsertaan kita dalam penderitaan Kristus sendiri. Apabila kita rela menderita bersama dan untuk orang-orang yang menderita, maka di hadapan kita ada misteri Paskah Kristus. Sebagaimana Yesus tampak lemah dan tidak berdaya ketika mengalami penderitaan dan kematian di salib, namun diangkat dan dimuliakan berkat daya kebangkitan-Nya, maka semua kelemahan dan penderitaan kita karena kasih akan diresapi oleh kekuatan Allah yang mengalir dari salib Yesus sendiri. Akan tetapi, kita harus mengakui bahwa kerelaan kita untuk menderita bersama dan untuk orang lain bukan karena kekuatan manusiawi kita, melainkan karena kekuatan Yesus Kristus sendiri. Dia menganugerahkan kekuatan-Nya yang menyelamatkan kepada kita semua. Dia sudah menetapkan keputusanNya untuk menyelamatkan kita melalui jalan penderitaan-Nya, yaitu melalui kelemahan dan pengosongan diri-Nya. Justru pada tataran inilah Dia menyatakan kekuatan dan kemuliaan-Nya ${ }^{87}$.

Penyataan diri Kristus yang kuat dan mulia dalam kelemahan dan pengosongan diri-Nya ini mengajarkan kita bahwa dalam penderitaan terkandung panggilan khusus untuk menghidupi keutamaan ketekukan dalam melakukan apa pun, walaupun membingungkan dan mendatangkan kerugian bagi diri kita sendiri. Dalam ketekunan terkandung keyakinan dan harapan bahwa penderitaan tidak akan mengalahkan dan merampas martabat kita sebagai manusia yang sungguh-sungguh sadar akan makna hidup ini. Keluhuran martabat kita bersumber dari Allah dan karya kasih-Nya yang rela menderita bersama dan untuk kita. Apabila kita ambil bagian dalam kasih, kita akan menemukan diri kita secara penuh dan utuh dalam penderitaan. ${ }^{88}$

Paulus memberikan kesaksian imannya bahwa dia menemukan kembali jiwanya yang hilang justru karena penderitaan yang dialaminya. ${ }^{89}$ Dia juga bersaksi bahwa kerelaan untuk ambil bagian dan penderitaan Yesus akan membawa kita kepada persatuan yang dalam

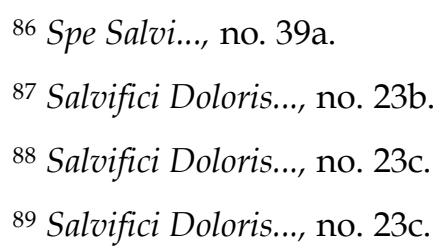


Alfonsus Ara,Kasih Yesus Kristus di Salib: Jawaban Tuntas atas Misteri ...

dan utuh dengan Yesus sendiri: penderitaan yang kita alami akan melengkapi apa yang kurang dalam penderitaan Yesus Kristus, yaitu Gereja, Tubuh Mistik-Nya sendiri. Kerelaan kita untuk menderita bersama dan untuk orang lain sudah dinyatakan sejak kita menerima baptisan: kita menjadi serupa dengan Yesus Kristus, dipersatukan dengan-Nya dan dengan semua anggota Tubuh-Nya, yaitu anggota Gereja yang menderita. Apabila kita rela menderita karena kasih kita kepada Yesus Kristus dalam diri sesama yang menderita, maka kita tidak hanya menerima kekuatan dari Yesus Kristus, tetapi juga "melengkapi apa yang masih kurang pada penderitaan Kritus" ${ }^{90}$

Dengan demikian tampak kebenaran iman bahwa penderitaan Yesus Kristus bersifat kreatif sebab menciptakan kebaikan, yaitu penebusan dunia. Kebaikan-Nya tidak berujung, tanpa batas dan tidak akan pernah berakhir. Tiada seorang manusia pun yang mampu menambahkan sesuatu pada kebaikan yang dinyatakan Yesus Kristus ini. Dia sudah menyatakan penderitaan-Nya yang menyelamatkan kepada kita, orang-orang yang menderita. Sejauh kita ambil bagian dalam penderitaan-Nya, dengan caranya sendiri, kita melengkapi penderitaan Kristus ketika Dia rela memikul penderitaan kita, demi keselamatan kita. ${ }^{91}$

Keyakinan iman Paulus ini tidak mengandung arti bahwa penderitaan Yesus Kristus itu tidak sempurna. Maksud yang terkandung dalam keyakinan iman Paulus ini justru menegaskan bahwa karya penebusan Kristus yang lahir karena kasih untuk keselamatan kita tetap dan selalu terbuka terhadap kasih yang dinyatakan dalam kerelaan kita untuk menderita bersama semua anggota Gereja yang menderita. Ini berarti bahwa karya penebusan itu diwujudkan secara sempurna oleh Kristus dan harus selalu disempurnakan dalam diri anggota Tubuh-Nya yang menderita. Inilah hakekat dari penderitaan yang menyelamatkan dalam diri Kristus: "penderitaan harus senantiasa dilengkapi dan disempurnakan". Tuntutan iman ini sangat logis sebab penderitaan itu tetap ada dan selalu berkembang dalam sejarah hidup kita. Konsekuensinya, penebusan Kristus harus senantiasa hidup dan berkembang dalam diri kita anggota Tubuh Mistik-Nya sendiri dalam

90 Salvifici Doloris..., no. 24a,b,c.

${ }^{91}$ Salvifici Doloris..., no. 24c. 
wujud kerelaan kita untuk menderita bersama Kristus terhadap semua orang yang menderita..$^{92}$

Kerelaan kita untuk menderita bersama dan untuk anggota Gereja yang menderita akan melengkapi penderitaan Kristus, seperti Gereja melengkapi dan meneruskan karya penebusan Kristus sendiri kepada dunia yang menderita. Hanya dalam tataran inilah, Gereja, Tubuh Kristus akan berkembang dalam ruang dan waktu untuk meneruskan "apa yang masih kurang dalam penderitaan Kristus" demi kepentingan Tubuh Kristus sendiri, yaitu Gereja. ${ }^{93}$ Karena itu, Gereja dan semua anggota-Nya harus senantiasa menimbah sumber-sumber yang mengalir dari diri Kristus dan daya penebusan-Nya agar bisa meneruskan dan menyempurnakan penderitaan Kristus yang menyelamatkan dalam kerelaan untuk menderita bersama dan demi semua manusia yang menderita.

Inilah hakekat ilahi dan insani dari Gereja: anggota Tubuh Gereja mengalami penderitaan dan dalam penderitaan inilah, Allah menyatakan kasih-Nya dalam kerelaan untuk menderita demi penebusan dan penyelamatan semua anggota-Nya. Dengan demikian tampak bahwa penderitaan memiliki makna dan nilai yang baik dan unik bagi Gereja sebab dalam penderitaan terkandung kasih dan penebusan. Gereja harus menghadapi setiap penderitaan dengan sikap iman dan hormat dengan sikap iman yang utuh terhadap Sang Penebus karena daya penebusan-Nya sungguh-sungguh menyelamatkan semua manusia yang menderita. Gereja juga harus tunduk kepada Sang Penebus karena dalam diri-Nya tersimpan misteri yang tidak bisa dijelaskan secara tuntas dengan nalar manusiawi kita, kecuali dalam iman dan tindakan Gereja untuk melakukan seperti yang dilakukan Kristus sendiri, yaitu rela menderita bersama dan untuk orang-orang yang menderita karena kedalaman dan kebesaran kasih-Nya. ${ }^{94}$

Gereja, Tubuh Mistik Kristus mengemban tugas utama untuk menjelaskan hakekat penderitaan dan misteri penebusan yang terkandung di dalamnya kepada umat manusia yang berdiam di bumi ini. Namun, Paus Yohanes Paulus II menegaskan bahwa Gereja hanya mampu menjelaskan dan bisa menjadi jalan keselamatan bagi orangorang yang belum mengenal dan mengimani Yesus Kristus sebagai

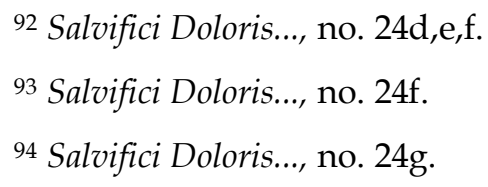


Alfonsus Ara,Kasih Yesus Kristus di Salib: Jawaban Tuntas atas Misteri ...

Allah dan Penebus apabila Gereja sungguh masuk ke dalam kehidupan Yesus yang menderita dan wafat di salib dan penderitaan sungguhsungguh masuk dalam hidup Gereja sendiri. Melalui penderitaan Yesus Kristus, Gereja menjumpai semua orang yang belum mengenal dan mengimani-Nya untuk menyatakan bahwa di sepanjang kehidupan di dunia ini, manusia pasti berjalan melewati lorong penderitaan. Gereja lahir dari misteri penebusan Yesus Kristus di salib. Gereja diutus untuk menjumpai semua manusia di lorong penderitaannya. Dalam perjumpaannya ini, "manusia menjadi jalan bagi Gereja" untuk memberikan kesaksian imannya bahwa penderitaan merupakan jalan yang paling penting untuk menggapai keselamatan. ${ }^{95}$

\section{Penutup}

Tiada hidup tanpa penderitaan. Penderitaan adalah bagian dari hidup yang harus ditanggung, walaupun dengan perasaan takut dan cemas, sebab penderitaan itu berasal dari kodrat kemanusiaan kita yang terbatas. Dengan cara apa pun, kita tidak akan pernah mampu menghilangkan penderitaan dari diri dan kehidupan kita di dunia ini. Penderitaan tidak akan bisa dilenyapkan. Penderitaan hanya bisa dikalahkan oleh Allah sendiri.

Yesus hadir di salib bukan untuk mengakhiri dan melenyapkan penderitaan dari sejarah kehidupan kita. Dia hadir di salib untuk mengajarkan kita bagaimana seharusnya menghadapi dan mengalahkan penderitaan. Penderitaan bisa dikalahkan, bukan dengan cara "menghindari penderitaan, atau "menyingkir dari penderitaan", melainkan "dengan kemampuan menerimannya". Apabila kita berjuang untuk menerima setiap bentuk penderitaan dalam kehidupan kita, maka kita akan dimatangkan oleh penderitaan dan menemukan makna dari setiap penderitaan yang dialami dalam kehidupan kita berkat persatuan kita dengan Yesus Kristus yang menderita karena kasih dan memiliki kasih tanpa batas.

Yesus Kristus menghadapi dan mengalahkan penderitaan dengan cara-Nya yang unik dan radikal. Dia tidak menghindar atau melarikan diri dari penderitaan, melainkan "masuk ke dalam kehidupan kita yang penuh penderitaan, ambil bagian dalam penderitaan kita, mengenakan penderitaan kita pada diri-Nya sendiri serta menebus penderitaan dan kematian kita dengan penderitaan dan kematian-Nya

95 Salvifici Doloris..., no. 3-4. 
sendiri". Penderitaan dan kematian tidak mengakhiri dan tidak menghancurkan hidup-Nya yang agung. Dia yang rela menderita karena kasih-Nya kepada kita justru bangkit mulia. Dalam kebangkitanNya, kita menemukan cahaya yang sama sekali baru, yaitu cahaya kasih yang menuntun kita untuk berani menghadapi keraguan, keputusasaan dan ketakutan dalam menghadapi penderitaan.

Kasih Yesus adalah sumber terkaya, penuh dan utuh untuk menjawab dan menjelaskan semua misteri penderitaan yang kita alami. Kasih Yesus yang tersalib adalah jawaban tuntas atas pertanyaan dan gugatan manusia kita Allah mengenai adanya penderitaan. Agar kita mampu menemukan makna penderitaan dan menerima setiap penderitaan yang dialami, kita harus mengontemplasikan daya kasih Yesus, hidup dalam kasih dan rela berbagi kasih dengan sesama yang menderita. 
Alfonsus Ara,Kasih Yesus Kristus di Salib: Jawaban Tuntas atas Misteri ...

\section{DAFTAR PUSTAKA}

Yohanes Paulus II, Paus. Surat Apostolik Salvifici Doloris (Penderitaan yang Menyelamatkan) (Seri Dokumen Gerejawi no. 29), diterjemahkan oleh J. Hadiwikarta (Jakarta: Departemen Dokumentasi dan Penerangan KWI, 1993).

Ensiklik Dives in Miscericordia (Kaya dalam Kerahiman (Seri Dokumen Gerejawi no. 99), diterjemahkan oleh A. Alfons S. Suhardi, OFM \& B. F. Adisusanto, SJ (Jakarta: Departemen Dokumentasi dan Penerangan KWI, 2016).

Benediktus XVI, Paus. Ensiklik Spe Salvi (Harapan yang Menyelamatkan (Seri Dokumen Gerejawi no. 88), diterjemahkan oleh Mgr. Hadisumarta, O.Carm \& Mgr. A.B. Sinaga, OFM Cap (Jakarta: Departemen Dokumentasi dan Penerangan KWI, 2014).

Muller, Gerhard Ludwig. Dogmatica Cattolica: Per lo Studio e lla Prassi della Teologia (Milano: San Paolo, 1999).

Bergant, Dianne, CSA. - Karris, Robert J. OFM (ed). Tafsir Alkitab Perjanjian Lama (Yogyakarta: Penerbit Kanisius, 2002), hlm. 40-41.

Kushner, Harold S. Derita, Kutuk atau Rahmat: Manakala Kemalangan Menimpa Orang Saleh. Judul asli: When Bad Things Happen to Good People, diterjemahkan oleh A. Supratiknya (Jakarta: Kanisius, 1987).

Podimattam, Felix., "Why Would A Good God Allow Suffering”, dalam Indian Theological Studies, vol. XLII, no. 2 (Juni 2005).

Mascarenhas, Fio. "A Spirituality to Cope with Suffering", dalam Vidyajyoti, vol. 69, no. 10 (Oktober 2005). 